$\begin{array}{r}\text { Volume and Issues Obtainable at Center for Sustainability Research and Consultancy } \\ \text { Journal of Business and Social Review in Emerging Economies } \\ \text { ISSN: 2519-089X (E): 2519-0326 } \\ \text { Volume 6: No. 4, December 2020 } \\ \text { CSRᄃ } \\ \text { Journal homepage: www.publishing.globalcsrc.org/jbsee } \\ \hline\end{array}$

\title{
Early Marriage in Pakistan: So Little Done, but So Much to Do
}

\author{
${ }^{1}$ Uzma Ashiq, ${ }^{2}$ Nargis Abbas, ${ }^{3}$ Amir Zada Asad \\ ${ }^{1}$ Lecturer, Department of Social work, University of Sargodha, Pakistan, uzma.ashiq@uos.edu.pk \\ ${ }^{2}$ Assistant Professor, Department of Education, University of Sargodha, Pakistan, \\ nargis.abbas@uos.edu.pk \\ ${ }^{3}$ Department of Social work, Univerity of Peshawar, Pakistan,
}

\begin{tabular}{l} 
ARTICLE DETAILS \\
\hline History \\
Revised format: November \\
2020 \\
Available Online: December \\
2020 \\
\hline
\end{tabular}

Keywords

Maternal mortality; Poverty;

illiteracy; School drop-out

rate, Cultural value

JEL Classification

MO, M1
ABSTRACT

Marriage is a human social institution which lays the foundation of a family as a unit of a society. It has been happening in human societies since the dawn of the creation but with varying degree of celebrations, customs and traditions, modes and manners etc. It is regarded as a moment of celebration and joys not only for the couple who are going to lock in weddings, but in many parts of the world, it is a moment of joy and celebration for the blood relatives as well as the entire community. Unfortunately, it does not happen always especially in the case of early marriage. In such case, it does not give such a cause of celebrations to the wedding couple rather it imposes on them without their consent or informed consent. The practice of early marriages has been in vogue from time immemorial, but all its negative impacts whether social, economic, physical or psychological, are realized since the late 20th century. This literature based article highlights the concept, practice, causes and consequences of the child marriages with special reference to Pakistani society. It was concluded that by increasing literacy rate among the people and through educating them, the issue of early marriages may be minimized/dealt.

(C) 2020 Center for Sustainability Research and Consultancy Pakistan under a Creative Commons Attribution-NonCommercial-ShareAlike 4.0

Corresponding author's email address: uzma.ashiq@uos.edu.pk

Recommended citation: Ashiq, U., Abbas, N. \& Asad, A. Z. (2020). Early Marriage in Pakistan: So Little Done, but So Much to Do. Journal of Business and Social Review in Emerging Economies, 6(4), $1449-1456$

\section{Introduction}

Marriage is a human social institution which lays the foundation of a family as a unit of a society. It has been happening in human societies since the dawn of the creation but with varying degree of cultures, customs, religious norms, traditions etc. These various elements further vary from region to region, tribe to tribe and sometimes family to family. Generally, marriage age of a girl is related with the commencement of her puberty, which may be variant in different parts of the world. For example, in Asian countries usually girls attain their puberty before their teenage due to climate and racial factors (Butts \& Sheifer, 2010). In addition, due to religious obligations against premarital sexual relationship, marriage of the girl is preferred as soon as she attains her puberty. However, marriage at this age before 
adolescence is considered as the early marriage. To have a clear idea of what constitutes an early marriage, it is important to have a valid definition of the term. Internationally, an early marriage is understood as said by United Nations (1998),

"a marriage or wed lock wherein one or both of the marrying partners are a 'child' and internationally a child is understood as a person less than eighteen years of age unless the law applicable to the child, majority is attained earlier".

In Pakistan, however, under the century old law known as The Child Marriage Restraint Act 1929

"A marriage is a child marriage if the male is under eighteen years of age and/or the female is under sixteen" (Shaukat, 2015, p. 201).

Therefore, the practice and concept of a child and early or child marriage differs from one country to another. Moreover, according to a UN report, six hundred thousand children-brides/ groom in Pakistan are married every year or 1650 children per day (United Nations Organization, 2013). Quoting a report of a national NGO the Blue Veins, the Express Tribune, an online daily reported that;

"About 60 million children were married around the world during 2014 which were under the age of 18 years. Out of this number $24 \%(144,000,00)$ were from rural Pakistan and 18\% $(108,000,00)$ from urban Pakistan" which means a total of 2,520,0000 children in Pakistan were married (Express Tribune, 2013).

Another report confirms these statistics and says that $21 \%$ of the brides in Pakistan are married before eighteen years (United Nations, 2015), while another report of this International Organization marking the nineteen years period (from 1987 to 2005), reported that in urban region of Pakistan total child marriages reaches to $21 \%$ of the children population, while in rural areas, the figures go well above $37 \%$ giving an average of $32 \%$ of all the marriages of the underage population (GOV, 2015).

A United Nation report quoted by The Dawn Newspaper reported that in ten years (marking 2011-2020) over 140 million children will become child-brides and grooms. It is apprehended that if this level of child marriages remains constant, 14.2 million children annually or 39,000 daily will be married out in their childhood. The same report also has estimated that out of the 140 million children who will be married out, 50 million will be less than 15 years of age (Dawn, 2015).

In 2012, print media in Pakistan reported 75 such cases and out of this number, 43 per cent children were 11-15 years old while 32 per cent were too young for marriage that were between the ages of 6-10 years. In 2008-2009, 24,228 children of 10-14 years and 10, 29,784 children of 15-19 years were reportedly married. This is a tip of the iceberg as mostly, such marriages are never reported (Express Tribune, 2015). Even the approximate numbers of such weddings cannot be made available due to poor official statistics compilation and data collection. A best example of this official negligence can be that Pakistan could not conduct population census for the last seventeen years (since after 1998) which could help to comprehend the issue. Moreover, the Pakistan Demographic and Health Survey 2006-07, mentioned that that 50 percent of the girls at age of 15-18 years were either expecting or already mothers (Government of Pakistan, 2007).

In the most report of Save the Children recent statistics reported by Tribune Express (2020); it was stated that;

"Pakistan is ranked $88^{\text {th }}$ out of the 144 countries where underage marriages, compounded by discriminatory social norms, affect large numbers of girls. In Pakistan, because early marriage is attributed to poverty and the lack of education, women suffer at multiple stages of their lives".(Seema Shakeel, 2020).

\subsection{Province Wise Practice of Early Marriages}


According to a UNICEF report, the early marriages practice in Pakistan is concentrated in the countryside as compared to the cities so much so that $58 \%$ females and $18 \%$ males of the country-side marry before 20 years, while $27 \%$ girls and $5 \%$ boys get marry in the cities. Not only there exists a difference between rural and urban areas, there is marked difference in the statistics of early marriages between the four federating units of Pakistan namely Punjab, Sindh, Kheber Pakhton Khwah (KPK) and Baluchistan. The regional statistics shows that Sindh province on the top of the pre-20 marriages with $72 \%$ females and 26\% males in the selected sample (Government of Pakistan, 2015). Similarly, Baluchistan is the second after Sindh in terms of pre-20 year marriages in the rural set up with $22 \%$ males and $63 \%$ females. Moreover, urban areas of Baluchistan have a lead in early marriages with $9 \%$ males and $56 \%$ females for the same age group (Government of Pakistan, 2015).

Meanwhile, KPK is the third in this regard, as $63 \%$ rural women are married out before attaining 20 years age. In this province, the rural men of the same age group have the least figures of $8 \%$ who are married. Punjab province has a record of having most males and females who get marry in their post-20 both in urban and rural set up (Government of Pakistan, 2015). While the pre-20 figures for such marriages are $50 \%$ for rural and $20 \%$ for urban areas of Punjab. As a trend, men in cities of Punjab marry even in their thirties. A little number (4\% ) marry in their pre-20 (UNFPA, 2012). These figures are blurred by the custom of "Pet Lekhai" in southern Punjab where a girl child is betrothed for exchange before she is born or still in the womb, a consequence of the custom of exchange marriage or marriage by purchase (Shaukat, 2015).

\subsection{Causes of Early Marriage}

Early marriages in Pakistan are based on cultural customs, traditions and the customary practices. Culturally, there is a number of modes of marriage including marriage by exchange, marriage by purchase (to settle debts and disputes), arranged marriages, elopement or court marriages etc. In the exchange mode (Vani or Watta Satta) of marriage a young daughter or sister is mostly exchanged for a women (wife) irrespective of the age of the bride-groom or number of already existing wives and such marriage can take place without any publicity, sanctioned by a Jarga or Panchayat (A local judiciary system in pakistan). Other reasons include the traditional tribal and feudal structure and social organization of the society, unawareness of the general masses about the corrosive effects of early marriages and the extreme poverty (Tremayne, 2006). Again, Child marriage is a subject of morality and not legislation (Stevenson, 2017). How come morality be legislated?

The ongoing controversy among the clergy, the civil society and the state has made an issue out of a problem. Mostly, it is misinterpreted that religion and the clergy is on the back of the problem and perpetuating it but it should be noted that Islam has nothing to do with minor things like child marriage (Lau, \& Ho, 2018; Liepert, 2011). At least it has declared a rule of marriage that is puberty and that is it. Islam does not say how long after the onset of puberty a marriage is valid or invalid. The other important reason is poverty. If we examine the causative factors of early marriages in Pakistan, poverty emerges as another major cause effecting the child/early marriage situation in a number of ways viz-a-viz the mode of marriage particularly (Ogwumike \& Ozughalu, 2018). Here are listed some of the major causes below.

\subsection{Economic Constraints due to Poverty}

Feeding a mouth by a poor father or mother is extremely difficult for a family. The best way to adjust such a situation is the early marriage of the daughter so that the family can save rather than spending on her living and education. In many poor families, the marriage by purchase or sale and exchange is prevalent. In marriage by purchase a human being becomes a 'slave' than a wife and she is subjected to all forms of violence including sexual relations. If, for example, poor family wants to marry a son, they have either to pay the bride price or will exchange a daughter for a daughter-in-law. The exchange marriage is also means of acquiring wife by a widower or a person want to have a second or third wife irrespective of the age differentials. Not only the purchase mode becomes a family matter but in some 
cases in southern Punjab like, in Cholistan desert, it becomes a clan's responsibility to acquire a wife for a young male member. In this case, the entire clan contribute towards the cost of the bride price and the custom is known as Phorhi (Shaukat, 2015).

\subsection{Honour and Safety of the Grown Up Girls}

In poor families, if father and mother or both go for work, it is difficult for the family to leave such a grown up girl at home unattended. In such cases, either the girl has to be put to child labour or be married out earlier to safe guard her chastity. In this aristocratic and feudalistic culture, it is difficult for poor people to save their girls from exploitation by the upper class. We read every day these like stories in newspapers and can infer that there is a relationship between female chastity and family honour which conditions the poor parents in particular to marry out girls child earlier to avoid sexual molestation of a girl and the resultant loss of family honour (SPARC, 2013).

\subsection{The Phenomenon of Child Mortality}

Some years ago, in Pakistan, child mortality was rampant and it is still nearly 314/1000 live births in interior Sind (UNICEF, 2015). Parents were never sure of the survival of their children particularly the male children. In order to satisfy their internal love and affection, parents use to marry their male children in particular very early to see them in the wedding dress or SEHRA ON THEIR HEADS. Now a days due to slow down of the child mortality, the trend of early marriage has also slowed down.

\subsection{Consequences of Child Marriage}

We have discussed the causes and said that parents consider cultural, social and financial aspects to wed their daughters at an early age. Unfortunately, what is not considered, are the consequences that such early marriages can have on young girls. Over the last few decades, a decrease has been observed in the frequencies of early marriages but this decrease is less for girls than boys (Bhattacharyya, 2016). The consequences of child marriages are many and disastrous in terms of the physical and psychological health of the girl in particular, literacy level among the school age children, school drops outs etc (Liu, Holmes \& Zhang, 2018). The following are some of the negative aspects of early marriages with respect to Pakistan.

\subsection{Child Mortality}

One such consequence is that of early childbirth which, directly results in greater vulnerability related to biological and physiological complications. Researches show that for a mother under the age of 18 the fatality rate of her child is 60 percent greater than those of a child whose mother is above the age of 19 (UNFPA, 2012). Even if such children survive, they will have low birth weight and are mal-nourished. This will cause the stunting of the child's physical and mental growth.

\subsection{Deprivation from Childhood}

The age of 8-12 years is the age of plays and enjoyments for the children irrespective of the financial status of the family and parents. By forcing such children into a wed lock means they are assigned 'adult roles' and they are no more children. This is unnatural and is tantamount to snatching the God gifted childhood from the innocent children who are not yet ready to shoulder the hard facts of life. The young girls are separated from their familiar surroundings, and are isolated and alienated.

\subsection{Maternal Mortality}

There has been a close relationship between early pregnancies and the increased risk of premature abortions and complicated labour, low birth-weight and a higher chance of child and maternal mortality (Judith, 1995). Pakistan has already highest child and maternal mortality rate in the region. This high rate can only be attributed to Pregnancy-related complications among 15-19 year-old girls in particular. According to experts there is a 20 to 200 percent greater chances of maternal deaths among women aged 15-19 than women who marry in the age between 20 and 24 years (Express tribune, 2013). According to Center for Reproductive Law and Policy (1999) the main causes of these maternal deaths are: 
"hemorrhage, sepsis, pre-eclampsia/eclampsia ${ }^{1}$ and obstructed labour. Unsafe abortion is the other major risk for teenage women - most of those affected are unmarried"

The World Health Organization and the UN department of Economic and Social affairs have explained the relationship between early marriages and maternal mortality as "Child wives fall ill and frequently die which explaining the highest maternal deaths in many countries" (United Nations Organization, 2000). It is now proved that young girls, who gestate before 15years of age, are at risk of death five times greater than girls gestate after 20 years of age ${ }^{2}$

\subsection{Gynecological Complications}

Teen pregnancy, particularly below 15 years of age, brings disastrous consequences for young women. In the teen early or pregnancies, there is every likely hood of an increased risk of Obstetric Fistula* as their small pelvis and the tender birth canal obstructs the smooth delivery or labour. Such pre-15 years mothers have $88 \%$ chances of such fistula (Nour, 2006). Fistula is a very painful, infectious complication wherein the victim has no control over urine and stool, a disability not only causing physical agonies but socially a shame as the patient cannot stay with people due to unbearable smell. In most cases such women are shunned not only by the community but by the husband as well, if not repaired through a prolonged surgical procedure (Cook et al., 2004).

\subsection{Emotional and Mental Effects}

Like adult women, a teenager girl is not able to fulfill the expectations of her husband and in-laws effectively which leads to domestic discords in the form of verbal, psychological as well as physical abuse of the girl. Mental health of the girls here becomes a huge cause of concern, as the victims of such torture often become hysteric. These young girls who are either sold or exchanged for marriage in particular, are not allowed to meet their parents or visit their maternal houses and end up feeling estranged in their new surroundings. There is no psychological support and consolation to these mentally estranged victims. These circumstances take a turn for the worst when the uneducated and traditional mind-set of the communities misunderstand the girl's plight and take it as some form of paranormal influence. Girls are often thought to be possessed by Jinn's (evil spirits) and are taken to local traditional healers Aamil or Mulla or soothsayers who mostly, inflict severe physical torture upon these young girls to drive out the evil spirit or Jinns (Baig, 2010).

Early marriages also hinder personality development and physical growth of the teen agers as a the child has to undergo constant physical, intellectual and emotional changes before attaining mental adulthood. In Pakistan the differential in marriages is high and child brides are sometimes married to much older men and making the girls are subjected to submission towards their older husband as towards father and mother in own home. Consequently, intimacy between them may be a joy and satisfaction for the husband but may be a labour for the young girl.

Another associated problem with this mismatch is the risk of becoming widow in a very young age is also writing on the wall as the older husband has to leave this world earlier as a natural phenomenon (Abbas et al., 2020). Resultantly, the young widow girl may face many socio-economic challenges. This means a widow is left with her orphan children. Such young widows remain unhappy due to their long inability to support the family and make such girls to attempt suicides or elopement with young males which ultimately lead to their killing known as "honor Killing" and even unhappy after remarriage.

\subsection{Illiteracy, Drop-Out and Low Education}

\footnotetext{
${ }^{1}$ In gynecological terminology a Fistula is a rupture or hole or passage between organs specifically between the feminine vagina and the rectum or between the vagina and the urinary bladder mostly caused by an obstructed or delayed labor. This is a very troublesome problem where women have no control over the urine or stool
} 
The most disastrous effect of such marriage is the low literacy level of women. In Pakistan, the women literacy rate is already deplorable and we are constantly adding un-educated women to the existing lot. Early marriages leave the young girls dropped-out from the school or compel her to leave her education incomplete (Wahab et al., 2018). Mentally capable and intelligent girls, who can do well in academics and can have a rewarding career in life, are forced to drop out. It is now established that there correlation between child marriages and a low literacy level. It is a matter of common observation that in both, rural as well as urban Pakistan, 60\% girls who never attended a school are married before their $20^{\text {th }}$ birth day. There is always a decrease in early marriage with increase in educational level. Sample surveys reveal that even primary level of education decreased the intensity of early marriage by $19 \%$ ( from 68 to 49 percent) for girls while nine years of education decreased the intensity of early marriages up to $33 \%$ and over ten years or secondary and higher secondary level education reduced early marriages to $13 \%$. Similar can be the case for boys as well. It is researched that $29 \%$ boys who never attended school married before 20 while primary level of schooling reduced the percentage of early marriages of males to $14 \%$ and high school or college level education reduced the intensity of early marriages among boys to $8 \%$ (Population Council, 2015).

\subsection{Population Growth}

Child marriage are also a cause of higher rate of population growth as the teenage brides are in a more fertile age and start to bear children from a young age till late age. Early marriages lead to higher fertility rate and hence higher population growth rate.

"The earlier they [young girls] get married, the more child-bearing years they have" (Dakuyo \& Jean, 2010)

Girls who are married early, are mostly unaware of contraception methods nor can discuss it with husband or mothers-in-law because producing more children is always the choice of the parents-in-law. Consequently they have mostly unplanned gestations. This contributes towards Pakistan's already burgeoning population.

\section{Conculsion and Recommendations}

The trend of early marriages in Pakistan encompasses the factors like; physical \& socio-cultural security of girls, and girl child. It produces the fear among the parents of daughters in terms of girl child abuse, rape, late marriages or unmarried old age daughter. Socially, value system of Pakistani society demands sex segregated society and any kind of sexual or emotional involvement of girls before marriage is strictly punishable in the society. Keeping these circumstances in view, parents prefer early marriages of their daughters. Amongst the physical issues, the cases of girl rape are still prevailing in the community around us. When such incident happens, it ruins the reputation of the whole life of a girl as well as of her whole family, and in result, no one is willing to marry her. Culturally, raising a daughter is considered as 'watering a neighboring tree' (Malik, 2005) hence she is thought of an economic burden and consequently she needs to be married as she reaches puberty. On the other hand, the parents' decisions of their daughter's early marriages is resulting in increased chances of many health hazards and sexual transmitted diseases among the families.

The solution of this trend is, firstly to render awareness about health believes and concerns of the people regarding overall health issues due to early marriage. The organizations working for this issue, scholars and govt may have necessitation's to amend these issues. To address this issue of early marriage due to economic burden, poverty prevention/reduction strategies among girl child families' may be another way out. This idea may be achievable through the introduction of small business, entrepreneurship and cottage industry which will ultimately not only empower to the families of girl child but also to the girls in itself in the long run.

In nut shell to attain this goal step by step programmes can be introduced, like at first hand there is need to deal with belief system of families for the girl child as a burden and source of threat to the respect of 
family in case of any miss happenings. Secondly, there is immense need of inculcating awareness of rights of the girls among the parents. Thirdly, skill development and enhancement programmers for girls and fourthly, small loans strategies for small business and entrepreneurship should be provided by government especially in remote areas. Last but not the least we can connect the families of girl child to outer developed world through social media and motivate them properly to tackle the prevailing early marriage problem. If the issue should not be deal at earliest and urgent bases it may lead to a voluenarable group of child wife's and potential mothers of mentally and physically disordered new borns.

But the flip side of the picture has another angle which reveals the measures taken by the government of Pakistan to deal with the security of early girls' marriage issue. Keeping in view the severity of physical and socio-cultural security of girl child, the government has promulgated legislation like Hudood Ordinance (rape), 1979. Further it has fixed the marriage age as 18+ to empower women and to secure women health issues through Muslim family Law Ordinance, 1961. But the good governance of the policy and implementation of law in its true soul are still lacking in the country and no serious actions are taken in all the cases of early marriages. There is a strict need to create awareness among the citizens by the Government organizations (GOs) and NGOs. Further the rule of law in case of rape crime need to be enforced in the country.

\section{References}

Abbas, N., Abrar ul Haq, M., Ashiq, U., \& Ubaid, S. (2020). Loneliness Among Elderly Widows and Its Effect on Social and Mental Well-being. Global Social Welfare, 7(3), 215-229. https://doi.org/10.1007/s40609-020-00173-5

Baig, Q. (2010). Adolescent Girls Empowerment: Real Life Accounts of Victims of Early Marriage, (Islamabad: Rutgers) p.19.

Bhattacharyya, R. (2016). Street violence against women in India: Mapping prevention strategies. Asian Social Work and Policy Review, 10(3), 311-325.

Center for Reproductive Law and Policy (1999). Implementing Adolescent Reproductive Rights through the Convention on the Rights of the Child. Washington DC, p.3.

Cook, R. J., Dickens, B. M., and Syed. S. (2004). Obstetric Fistula: The Challenge to Human rights. International Journal of Gynecology and Obstetrics 87(1),72-77. https://doi.org/10.1016/j.ijgo.2004.07.005

Dakuyo, Jean L. (2010). Early Marriages and Fertility (Burkina Faso: National Population Advisory Council), p.19.

Dawn. (2015, January 30). Anti-child marriage law. DAWN Newspaper, Retrieved on October, 25 from https://www.dawn.com/news/1160326

Express Tribune, (2015, October 13). Child marriage: The scourge of Khyber-Pakhtunkhwa. Retrieved from https://tribune.com.pk/story/971791/day-of-the-girl-child-child-marriage-the-scourge-ofkhyber-pakhtunkhwa

Express Tribune (2013, January 2). Child Marriage in Pakistan. Retrieved on November, 12, 2020 from https://ribune.com.pk/story/488062/child-marriage-in-pakistan

Government of Pakistan. (2007). Demographic and Health Survey of Pakistan, 2006-7. Islamabad: Population Census Bureau, p.111

Government of Pakistan, (2015). Pakistan Statistics retrieved on November, 12, 2015 from http://www.UNICEF.org/infobycountry/pakistan_pakistan_statistics.html (Study report Child Marriage in Pakista: A Taboo), p.1.

Judith, S (1995). Adolescent Health: Reassessing the Passage to Adulthood. World Bank Discussion (Paper no. 272), Washington DC.

Lau, Y. K., \& Ho, W. M. (2018). Family-centered kindergarten social work services in Hong Kong: A pilot project. Asian Social Work and Policy Review. 12(2), 116-126. https://doi.org/10.1111/aswp.12144 
Liepert, D. (2011, January 29). Rejecting the Myth of Sanctioned Child Marriage in Islam [Web log post]. Retrieved January 05, 2018, from https://www.huffingtonpost.com/dr-davidliepert/islamic-pedophelia_b_814332.html

Liu, T., Holmes, K., \& Zhang, M. (2018). Better educational inclusion of migrant children in urban schools? Exploring the influences of the population control policy in large Chinese cities. Asian Social Work and Policy Review, 12(1), 54-62.

Malik, A. H. (2005). Sociology of Gender Relations. Multan: Teachers Students Welfare Forum.

Nour, N. M. (2006). Health Consequences of Child Marriage in Africa. Emerging Infectious Diseases, 12(11), 1644-1649. https://dx.doi.org/10.3201/eid1211.060510.

Ogwumike, F. O., \& Ozughalu, U. M. (2018). Empirical evidence of child poverty and deprivation in Nigeria. Child Abuse \& Neglect, 77, 13-22.

Population Council (2015) Adolescents and Youth in Pakistan 2001-2010: A Nationally Representative Survey, Retrieved on December,12. 2015. from http://www.popcouncil.org

Seema Shakeel (2020, January 17). Child Marriage. Express Tribune. Retrieved from https://tribune.com.pk/letter/2138701/6-child-marriage-9.

Shaukat, A., (2015) The Changing Roles and Status of Women in Cholistan, Pakistan. (Peshawar University: Unpublished Ph.D. thesis), p.201.

Shaukat, A., (2015) The Changing Roles and Status of Women in Cholistan, Pakistan. (Peshawar University: Unpublished Ph.D. thesis), p.201.

SPARC (2013). Society for the Protection of the Rights of the Child: Child Marriage. Islamabad: p.1

Stevenson, K. (2017). 'Not Just the Ideas of a Few Enthusiasts': Early Twentieth Century Legal Activism and Reformation of the Age of Sexual Consent. Cultural and Social History, 14(2), 219-236.

Tremayne, S., (2006). Modernity and early marriage in Iran: A view from within. Journal of Middle East Women's Studies. 2(1), 65-94

UNICEF. (2015). The State of the World's Children 2014 . New York: UNICEF.

UNFPA. (2012). Child Marriage profile: Pakistan, 2012. Retrieved on 10 October 2020 from http://www.khubmarriage18.org/sites/default/files/statistical_information/Child\%20marriageProfile\%20for\%20Pakistan-UNFPA.pdf

United Nations. (1998). Convention on the Rights of the Children. Geneva: UNICEF.

United Nations (2015). The State of the World's Children 2015.New York: UNICEF, P.15.

United Nations Organization (1991). The World's Women 1990 (UN Department of Economic and Social Affairs: New York. p.5.

United Nations Organization (2000). Adolescent Sexuality, Safe Motherhood Fact Sheet 2000 WHO: Geneva.

United Nations Organization. (2013). Women aged 20 to24 married before 18(in thousands) UNICEF Council on Foreign Relations (Statistics and Monitoring Section, Division of Policy and Strategy, 2013).

Wahab, H. A., Bunyau, W., \& Rezaul Islam, M. (2018). Microcredit for rural poverty alleviation and social well-being: A study of Sabah, Malaysia. Asian Social Work and Policy Review, 12(1), 4-16. 